François Esvan

\title{
NĚKOLIK POZNÁMEK KE KONKURENCI VIDŮ: RÁNO JSEM VSTAL VS. RÁNO JSEM VSTÁVAL
}

\author{
SOME REMARKS ON THE ASPECTUAL CONCURRENCE: \\ RÁNO JSEM VSTAL VS. RÁNO JSEM VSTÁVAL
}

\begin{abstract}
In this article the author proposes to use the Czech National Corpus to investigate the use of the factual imperfective in comparison with the perfective aspect in a very specific context, but at the same time frequent, because of common use: ráno jsem vstával (a) vs vstal (a) 'the / this morning I got up'. The results show that the perfective is used predominantly in sequences of events and the factual imperfective in argumentative discourses (in both cases in the measure of $80 \%$ ). While the exceptions are functional for the imperfective in the narration, the presence of the perfective in the argumentative contexts appears random and testifies to the existence of a "gray area "in which the aspects are almost interchangeable.
\end{abstract}

\section{KEYWORDS}

Czech language; verbal aspect; factual meaning

\section{1 Úvod}

„Konkurencí vidů“ se v české lingvistice poprvé zabývá Vilém Mathesius ve své známé studii z roku 1938. Tímto termínem označuje možnost odkazovat k totožné "objektivní skutečnosti“ různými vidy s ohledem na potřeby „jazykové stylizace“ (Mathesius 1938, 15). Př́ípady vidové konkurence, jež zkoumá Mathesius (1938), se v zásadě týkají uplatnění dokonavého a nedokonavého vidu v imperativu a v tázacích větách, zejména pak, pokud se mluvčí dotazuje na autora určité činnosti. "Objektivní skutečnost" v prípadě otázky autorství je chápána jako ukončený děj, přičemž volba toho či onoho vidu vyjadřuje jemné rozdíly, které Mathesius (1938: 
16) interpretuje na základě obecného vymezení aspektové opozice v termínech „důrazu na vlastním výkonu“, kdy se používá imperfektivum, oproti „důrazu na výsledek činnosti“, co se týče užití perfektiva.

V souvislosti s předloženými odlišnostmi ve výpovědi, vyjádřenými skrze užití určitého aspektu, lze uvést, že např. perfektivum se uplatňuje v př́ípadě, že mluvčí pronáší pochvalu, přičemž zdůrazňuje dokončení jisté činnosti: Kdo vám to tak pěkně vymaloval? V ostatních př́padech je při výběru slovesa dokonavého či nedokonavého rozhodující předcházející kontext. Pokud již byl děj naznačen dříve, preferuje se užití imperfektiva, v opačném případě pak perfektiva. Při položení otázky Kdo vám boural? uvažujeme o kontextu, v němž bylo „bourání“ objednáno, jednalo-li se o incident, očekává se užití dokonavého vidu: Kdo vám to zboural/zbořil? Charakterizovat užívání nedokonavého vidu prostřednictvím „důrazu na vlastním ději“ poskytuje také možnost interpretovat jeho „emocionální“ užití, a to v otázkách, jež vyjadřují určitou výčitku: Pročjsi mu to dával? (Mathesıus 1938, 16-18).

Nelze říci, že by námi sledovanému fenoménu byla věnována zvláštní pozornost, s výjimkou současné studie Chlumské (2011), v níž na základě dat korpusu SYN2010 ověřje Mathesiova $(1938)$ tvrzení. Štícha $(2013,444)$ se ve své Akademické gramatice spisovné češtiny spíše omezuje na tezi, že rozdíly mezi zdůrazněním završenosti oproti průběhu a kvalitě děje nemusí být př́liš výrazné, přičemž určitý vid může být volen v souvislosti s územ jednotlivých vět a/nebo obsahem kontextů.

Na základě dřívější analýzy (Esvan 2011), v níž jsme se zabývali užíváním verb dicendi ř́ḱkat - říci v minulém čase, jež následují přímou řeč, lze poukázat na to, že slovesa dokonavá a nedokonavá není vždy možné zaměnit, jak předpokládá Kopečný $(1962,8),{ }^{1}$ a výběr užití jednoho nebo druhého aspektu ovlivňuje př́islušný kontext. Př́́klady, jež poskytuje Český národní korpus, potvrzují, že imperfektivum je upřednostňováno $\mathrm{v}$ př́ípadě, že určitá část přímé řeči má v př́slušném diskurzu argumentační hodnotu.

Při zkoumání dané problematiky navážeme na přechozí rozbor v tom smyslu, že budeme analyzovat data ČNK, a to v kontextu, jenž je z jedné strany velmi omezený, z druhé strany však velmi frekventovaný, jelikož se dotýká běžného života každého člověka. V tomto př́spěvku se budeme zabývat větami, které obsahují adverbium ráno a verba vstát a vstávat $\mathrm{v}$ minulém čase. Pozornost budeme věnovat nejen kontextům předcházejícím, ale také kontextům následujícím, se zvláštním přihlédnutím $\mathrm{k}$ př́śslušnému druhu diskurzu, v němž se námi sledované jazykové prostředky uplatňují, totiž vyprávění či argumentaci. 


\section{Rozbor dat}

Připomeňme, že nedokonavé sloveso vstávat může být s ohledem na dané textové souvislosti nositelem tř́ významů, a to 1) průběhového, 2) iterativního a 3) faktuálního, což v př́slušném pořadí ilustrují př. (1)-(3). ${ }^{2}$

(1) Důchodce zakopl, když vstával z křesla.

(2) Každý den jsem vstával $v$ šest hodin a hned si pouštěl zprávy.

(3) Ještě ve čtvrtek byl $v$ Japonsku, v pátek vstával ve tři ráno a jel autem z Německa.

1. Co se týče průběhového významu, o vidové konkurenci nelze hovořit, jelikož perfektiva a imperfektiva se užívají, použijeme-li Mathesiova termínu (1938, 15), v rámci odlišné „objektivní skutečnosti“. Tento faktor je možné znázornit konfrontací př̀. (1) výše a př. (1a):

\section{(1a) Důchodce zakopl, když vstal z křesla.}

Je patrné, že z hlediska časového zvolení dokonavého či nedokonavého slovesa ve vedlejší větě implikuje odlišný vztah mezi událostí, již tato popisuje, a událostí, jež byla vyjádřena ve větě hlavní - tedy shodu v případě užití imperfektiva, jako v př. (1), a následnost za použití perfektiva, což ilustruje př. (1a).

2. Slovesa rozdílného aspektu si konkurují, jsou-li použita v kontextu iterativním, v němž lze substituovat imperfektivum perfektivem a naopak, aniž by byl změněn význam př́slušné věty. Porovnejme na tomto místě př. (2) výše s následujícím př̀. (2a):

(2a) Každý den jsem vstal $v$ šest hodin a hned si pustil zprávy.

Tuto situaci plně potvrzují data ČNK, jelikož v obdobných iterativních kontextech nalézáme řetězce dokonavých i nedokonavých sloves. Tento aspekt lze ilustrovat př. (4) a (5), v nichž se uplatňuje sled imperfektiv, a př. (6) a (7), ve kterých se nachází sekvence perfektiv.

(4) Každé ráno jsem vstávala před pátou, pred šestou už jsem vystupovala z autobusu $u$ vrat léčebny a úderem šesté jsem se stávala sestřičkou. SYN2O15

(5) Každé ráno jsem vstával $v$ pèt hodin a chodil na ranní dynamickou meditaci, která začiná už $v$ šest. SYN2O15

(6) Každé ráno jsem vstala pred svítáním a dojela na kole ke stromu, kde ptáci hnízdili. SYN2O15

$2 \quad$ K významu imperfektiv v kontextu viz Esvan (2011). 
(7) Následujících čtrnáct dnů jsem byla v módu zombie. Ráno jsem vstala, pomalými pohyby jsem se vysprchovala, oblékla, učesala, když byla síla, tak i nalíčla, nasnídala a jela do práce. SYN2O15

Ve všech čtyřech výše uvedených př́ikladech, tak jako v př. (2) a (2a), se dokonavá a nedokonavá slovesa jeví jako volně zaměnitelná, přičemž užití jednoho nebo druhého aspektu by nevedlo ke změně významu dané věty. ${ }^{3}$

3. Fenomén konkurence vidů se uplatňuje také v kontextech, v nichž se imperfektiv a perfektiv užívá ve významu faktuálním. Tuto situaci lze znázornit na základě srovnání př̀. (3) výše a př. (3a):

(3a) Ještě ve čtvrtek byl v Japonsku, v pátek vstal ve tři ráno a jel autem z Německa.

Tento třetí $z$ předložených významů stojí $v$ popředí zájmů našeho př́spěvku. $V$ rámci rozboru konkurence vidů jsme analyzovali výskyt sloves vstal(a) jsem a vstával(a) jsem v korpusu SYNv3, ${ }^{4}$ přičemž užívání daných jazykových prostředků jsme sledovali $\mathrm{s}$ ohledem na použití adverbia ráno, jež figuruje v předcházejícím kontextu $[-5,0]$. Jakmile jsme vyřadili nevhodné textové souvislosti, zejména iterativní nebo takové, v nichž je adverbium ráno součástí jiné věty, získali jsme soubor př́kladů se 123/189 imperfektivy a 38/139 perfektivy. Na základě př́slušných dat jsme se následně pokusili vymezit kontexty, v nichž se určitý aspekt používá. Předložíme zde nejprve výsledky analýzy užívání dokonavého vidu (2.1), poté vidu nedokonavého (2.2).

\subsection{Ráno [...] jsem vstal(a)}

Rozbor užívání perfektiva vstal(a) jsem poukazuje na jasnou převahu výskytu této jazykové formy $\mathrm{v}$ kontextech, $\mathrm{v}$ nichž je daná aktivita zasazena do sledu po sobě jdoucích událostí (viz oddíl 2.1.1), přesto lze, ačkoliv vzácněji, pozorovat užití tohoto dokonavého slovesa také mimo něj (viz oddíl 2.1.2). Jednotlivým typům užívání daného perfektiva se budeme podrobně věnovat v následujících částech.

\subsubsection{Sled událostí}

\section{a) Následují další perfektiva: $\mathbf{N}=73$}

Řetězec událostí je ve velké většině př́ípadů vyjadřován perfektivem vstal(a) jsem, jejž následují další dokonavá slovesa v koordinaci se spojkou a, která předchází závěrečné sloveso. Tento základní model reprezentují př. (8)-(11):

\section{(8) Ráno jsem vstal z molitanové matrace a postavil se k oknu.}

3 Tomuto typu vidové konkurence se dále nebudeme věnovat a zaměříme pozornost na kontexty, jimiž se zabývá Mathesius (1938), čili textovým souvislostem, v nichž si konkurují perfektivní a impefektivní slovesa ve významu faktuálním.

4 Pokud užíváme data z jiných korpusů, zdroj uvádíme přímo za př́́kladem. 
(9) Ráno jsem vstal, sedl si k počitači a zjistil, že Richard užje vzhưru a taky sedí.

(10) Ránojsem vstala, sbalila si věci a odešla.

(11) Ránojsem vstal, udělal si snídani, vynesl kocoura na nádvoří, protože jsme zrovna $v$ tom čase bydleli na zámku, vyčistil si zuby a obul se.

Užití perfektivního slovesa je navíc kompatibilní s určitou specifikací daných okolností, za nichž př́slušná událost proběhla, obvykle s upřesněním časové povahy. Srov. př. (12)-(15):

(12) Ránojsem vstal $v$ sedm a jako obvykle jsem se osprchoval.

(13) V neděli ráno jsem vstal $v$ devět hodin, oholil se, vypral a prádlo pověsil na střeše.

(14) Ránojsem vstal současněs kokrháním kohouta a stihl první autobus.

(15) Ráno jsem vstal brzy a vylezl jsem na vysokou telekomunikační věž, abych shlédl svítání a viděl Alpy.

Veškeré výskyty perfektiva vstal(a) jsem však nelze zasadit do představeného základního modelu. Zásadní rozdíly ve způsobu užívání sloves mimo toto schéma lze pozorovat $\mathrm{v}$ př́padech, $\mathrm{v}$ nichž 1 . se nachází závěrečné imperfektivum, 2. vyprávění pokračuje další novou větou.

1. Závěrečným imperfektivem se označuje užití nedokonavého slovesa na konci sekvence událostí (zprostředkovaných slovesy dokonavými), přičemž mu obvykle předchází spojka a v koordinaci. Na tento fenomén, jenž je pro češtinu typický, ${ }^{\text {zde }}$ není v uvedených př́kladech vždy explicitně poukazováno, jelikož závěrečným imperfektivem bývají slovesa pohybu, jako např. jit, jet, běžet, která nedisponují perfektivním protějškem. Srov. př. (16) a (17):

(16) Ráno jsem vstal, posnídal, přečetl noviny, zavedl dítě do školky, šel do práce.

(17) Ránojsem vstala, oblékla se a šla se nasnídat.

Přestože imperfektivum $\mathrm{v}$ závěru věty je typicky reprezentováno slovesem pohybu, je možné užívání závěrečného imperfektiva jasně ilustrovat také př́íklady, ve kterých se nacházejí párová slovesa, jako je tomu v př. (18).

(18) Ránojsem vstal, připojil se na internet a prohlížel si české noviny.

2. Užívání dokonavých sloves stranou uvedeného základního modelu představují textové souvislosti, v nichž dané vyprávění pokračuje za použití perfektiv, která se však neuplatňují v rámci př́slušného souvětí, nýbrž v nové větě. Tento zpưsob narace znázorňují přs. (19) a (20): 
(19) Ve čtvrtek ráno jsem vstal $v$ půl šesté. Dvacet minut pred sedmou jsme se $v$ ordinaci dali do práce, čekal nás protetický den.

(20) Ve středu ráno jsem vstal $v$ šest hodin. Mimořádně jsem tentokrát prèece jen posnídal. A protože mèli přijít malírí vymalovat dětský pokoj, který byl našínedávnou „povodni“", kdy nám do bytu střechou neskutečně zatékalo, nejvíce postižen, museli jsme ho vystěhovat a pripravit k malování.

V obou př́kladech výše není vyprávění natolik plynulé jako při uplatnění koordinace. Lze upozornit na to, že v těchto př́padech následuje i komentář, v němž se podává odůvodnění předešlých dějů, což je typické, jak uvidíme dále (viz oddíl 2.2.1), pro kontexty, ve kterých se používají nedokonavá slovesa. Př. (19) a (20) se tedy jeví spíše jako mezistupeň.

\section{b) Následuje imperfektivum: $N=20+16$}

$\mathrm{K}$ tomuto způsobu narace, tedy $\mathrm{k}$ užití dokonavého a následně nedokonavého slovesa, jež není př́liš časté, dochází ve dvou typech kontextů, a to pokud imperfektivum 1. uzavírá větu (závěrečné imperfektivum), 2. označuje určitý stav.

1. Nedokonavé sloveso, které uzavírá danou větu, lze interpretovat jako závěrečné imperfektivum stejně jako ve výše uvedených př. (16)-(18), jež reprezentují řetězec několika událostí. $V$ př́padech, kdy verbum vstal (a) jsem následuje nedokonavé sloveso, se v podstatě jedná o sekvenci událostí omezenou pouze na dva členy, přičemž její poslední prvek se jeví jako závěrečné imperfektivum. Obdobně je možné pozorovat užívání imperfektiv také v kontextech, v nichž nacházíme jak slovesa, která nedisponují vidovým protějškem, jako je tomu v př. (21) a (22), tak i slovesa párová, což znázorňují př. (23) a (24).

(21) Ráno jsem vstal zároveň s Pavlínou a utíkal ke kostelu.

(22) Ráno jsem vstal $v$ osm a šel volat Jarkovi.

(23) V 6 ránojsem vstal a poslouchal na Rádiu Čtyři program pro zemédělce.

(24) Brzy ráno jsem vstal a dlouho jsem se na sebe díval do zrcadla.

2. Uplatnění imperfektiva lze sledovat $\mathrm{v}$ případech, kdy př́slušné nedokonavé sloveso nevystihuje událost, ovšem stav, který odpovídá určité percepci situace, jež doprovází či následuje aktivitu vyjádřenou prostřednictvím perfektiva vstát v minulém čase. Srov. př. (25)-(28):

(25) V úterý ráno jsem vstal a byl zdravý jako rybička.

(26) Ráno jsem vstal a prostě se mi nechtělo hrát.

(27) Ráno jsem vstal a Martin byl pryč.

(28) Drahý pane Kolár̆, ráno jsem vstala a v pokoji bylo čtrnáct stupňů, venku mráz. 
Užití nedokonavého slovesa je možné pozorovat také mimo př́pady v koordinaci, jako je tomu v př. (29):

(29) Ránojsem vstal poměrně brzy. Slunícko sice už svítilo, ale bohužel ne na můj stan.

\subsubsection{Mimo sled událostí: $N=14$}

Dokonavé sloveso vstal (a) jsem lze použít také v př́ípadě, že v př́slušném textu není předkládán řetězec událostí, přestože se jedná o druh kontextu, v němž, jak uvidíme dále (viz oddíl 2.2.1), se obvykle uplatňuje sloveso nedokonavé. Významným faktorem není pouze to, že tento typ textových souvislostí, v nichž se užívá imperfektivum, se podobá kontextům, jež nereprezentují sled po sobě jdoucích událostí, ale také to, že v nich lze nalézt analogii k sekvencím argumentačního typu, zejména pak v př́padech, kdy je událost vyjádřená slovesem vstát a) uvedena v kontrastu vưči události jiné, $b$ ) předkládána $v$ textu, jenž vysvětluje okolnosti, za kterých tato aktivita proběhla. Tyto dva zvláštní druhy kontextů ilustrují př. (30) a (31), jež reprezentují určitý kontrast, a př. (32) a (34), ve kterých se objasňuje situace, při níž k vlastnímu vstávání došlo.

(30) Ráno jsem vstal $v$ domnění, žeje 7 hod., a ve skutečnosti bylo 6 hod. Tenhle posunutý čas jsem $v$ sobě nosil celý den, hodiny nehodiny.

(31) A navícjsem rozzlobený. Včera ráno jsem vstal s představou, že navštívím otcův hrob, a misto toho slyším samé vytáćky a důvody, proč ho nemůžu najit. Správce hr̉bitova si myslí, že jsem cvok, farář se se mnou odmítá bavit a tomu šmírákovi na úradě chybí dokumentace.

(32) Ve středu ráno jsem vstal dř́ve, než u mne bývá zvykem, už v pět hodin. Ještě před cestou do ordinace jsem si chtěl prostudovat koncepci zdravotnictví, jak ji předložila paní ministryně Milada Emmerová.

(33) Ráno jsem vstala radostně, bylo pondělí a v jednom magazínu celostátního deníku mi vyšel fejeton, tak jsem se měla na co těšit. No, když to tak probírám, tak se vlastně těším skoro každý den na nějaké noviny nebo časopisy, kde mi něco vyjde... Vstávám prostě radostně každé ráno! Magazín jsem si prohlédla hned $v$ parku, kde se náš Atíček nechal plně ovládnout puchy a pachy a cloumal se mnou na všechny strany, a byla jsem spokojená ještě víc.

(34) Ránojsem vstal dř́v, abych všechno stihl.

\subsubsection{Shrnutí}

Rozbor užívání slovesa vstal(a) jsem ukazuje, že toto perfektivum se v převážné většině př́padů uplatňuje v narativních kontextech, v nichž je daná činnost zasazena do sledu po sobě jdoucích událostí. Nejčastějším typem, jejž lze označit za základní model, je sekvence dokonavých sloves, přičemž je možné, aby slovesem uzavírajícím danou větu bylo sloveso nedokonavé (závěrečné imperfektivum nebo stavové 
sloveso). Nejběžnější druhy posloupností tak představují (a) a (b), přičemž je možné se setkat také s řetěžcem typu (c):
a) ránojsem vstal $(a)+\mathrm{Pf}+[. .]+a+.\mathrm{Pf}$
b) ránojsem vstal $(a)+P f+[. .]+a+.\operatorname{Impf}$
c) ráno jsem vstal (a) $(+a)+\operatorname{Impf}$

Sloveso vstal(a) jsem mimo sekvenci událostí je v narativních textech výrazně méně zastoupeno. Jeho užití, ačkoliv je také poměrně omezeno, je př́íznačné pro texty argumentačního typu, přičemž se toto perfektivum uplatňuje v zásadě v souladu se způsobem, jenž je charakteristický pro užívání imperfektiv (viz oddíl 2.2.1 níže).

Statisticky lze představené typy užívání slovesa vstát v minulém čase znázornit následovně:

\begin{tabular}{|l|l|l|}
\hline & Počet výskytů & Užití v procentech \\
\hline Řetězec událostí & 109 & $89 \%$ \\
\hline Mimo řetězec událostí & 14 & $11 \%$ \\
\hline Celkem & 123 & $100 \%$ \\
\hline
\end{tabular}

\subsection{Ráno [...] jsem vstával(a)}

Analogicky k rozboru výskytu perfektivního slovesa, také ke zkoumání užívání imperfektiva vstával(a) jsem je třeba přistupovat s ohledem na druh kontextu, v němž se toto sloveso uplatňuje - tedy zda se jej užívá v textech vykazujících se určitou argumentací (2.2.1), či v textech, v nichž je předkládán sled po sobě jdoucích událostí (2.2.2). Analýza výskytů verba vstával(a) jsem poukazuje na podstatné kvantitativní rozdíly v distribuci daného imperfektiva.

\subsection{1 Řetězec argumentačního typu: $\mathbf{N}=31$}

Soubor našich př́kladů poukazuje na rozličné kontexty, jimž však lze přisoudit společné vlastnosti: 1. je přítomen určitý komplement specifikující způsob, jakým $\mathrm{k}$ př́śslušné události došlo, a/nebo okolnosti, jež onu událost doprovázely; 2. dané okolnosti jsou rozmanitými způsoby zasazeny v diskurzu argumentačního typu. Analyzovaná data ČNK umožňují vymezit následující typy kontextů, v nichž imperfektivum vstával(a) jsem a) je uváděno v kontrastu k jiné události, b) následuje určitá motivace či vysvětlení této činnosti, c) následuje důsledek dané aktivity, d) odpovídá jistému vysvětlení, e) odpovídá určitému důsledku,f) koresponduje s řečnickou otázkou.

\section{a) Kontrast}

Nedokonové sloveso vstával(a) jsem se často užívá v rámci upřesnění způsobu, jímž tato činnost byla provedena, přičemž dané okolnosti jsou předkládány v protikladu k další události či stavu. Tyto aspekty ilustrují př. (35)-(38): 
(35) Do postele jsem padal pěkně unavený, ale ráno jsem vstával s chutí do nového dne.

(36) Po úterním zápase s Rumunkami jsem zůstala s týmem na hotelu, ale ráno jsem vstávala už pred pátou a jela do práce.

(37) Myšlenky jsem nebyl schopen. Jen k tomu jsem se stále vracel: ráno jsem vstával jako poddaný Rakouska, nyníjsem občanem svobodného československého státu. Jak je to podivné!

(38) Ráno jsem vstával s tím, že hraju za jedenadvacítku. Pak došlo k přesunu, o němžse $v$ týdnu uvažovalo.

\section{b) Následuje určitá motivace či vysvětlení}

Imperfektivum vstával(a) jsem bývá doplněno komplementem, který specifikuje, jak př́slušná aktivita proběhla, a/nebo jej blíže určuje z hlediska časového. Tyto průvodní situace jsou následně objasněny, obvykle za pomoci vedlejší věty př́ičinné uvedené spojkou protože nebo další větou, nezávislou na větě hlavní. Srov. př. (39) -(42), jež reprezentují odůvodnění prímé, a př. (43)-(45) znázorňující vysvětlení nepř́mé:

(39) Už ráno jsem vstávala naštvaná, protože v naši čtvrti nefungovala elektřina a za boha jsem nenašla svícku.

(40) Ránojsem vstával v jedenáct, protože večer jsem príijel pozdě z predstavení.

(41) V sobotu ráno jsem vstával $v$ šest hodin. $S$ manželkou jsme se totiž chystali do mého rodného města, do Znojma.

(42) Ránojsem vstával brzy, potřeboval jsem si něco zař́lit.

(43) Ve středu ránojsem vstával jako vždy patnáct minut po šesté. V práci jsme v 7.15 hodin měli u vedoucího kanceláre reditele okresního ředitelství Policie ČR pravidelnou poradu.

(44) Dnes ráno jsem vstával jako každý jiný den, bez zvláštních pocitů. Víme, že jsme pripraveni.

(45) Na pondělní večer jsem neměl nic naplánováno, byl jsem doma, chvílemi jsem se díval na televizi a chvilkami jsem četl knižku. Usnul jsem až k půlnoci. Ráno jsem vstával brzo, šel jsem na denní službu a ta začíná $v$ šest hodin. U benzinové pumpy se mi pravidelně stř́dají denní a noční směny a dny volna.

Dalšími častými př́pady, ve kterých jsou vyloženy okolnosti aktivity vyjádřené slovesem vstával(a) jsem, představují kontexty, jejichž pokračování je zprostředkováno vedlejší větou účelovou uvedenou spojkou aby, což ilustrují př. (46) a (47).

(46) Ránojsem vstával v sedm, abych si vyžehlil růžovou košili.

(47) $Z$ Karlových Varů jsem príjel o pưl páté a ráno $v$ sedm jsem vstával, abych se dostal na trénink do Trébíče. 


\section{c) Následuje určitý důsledek}

Řidčeji je možné se setkat s případy, kdy větu obsahující imperfektivum vstával(a) jsem následuje věta, jež poukazuje na určitý důsledek okolností, do nichž je př́islušná činnost zasazena, jako je tomu v přs. (48).

(48) Př́ítí ráno jsem vstával pozdě a modelky se mezitím sbalily a odjely.

\section{d) Vlastní činnost představuje vysvětlení}

Určité objasnění situace lze pozorovat také přímo ve větách, v nichž se užívá sloveso vstával (a) jsem. Tyto věty se mohou vyznačovat argumentační povahou, jelikož se vztahují k dříve uvedenému, přičemž obvykle podávají jisté vysvětlení. Tyto faktory znázorňují př̀ (49)-(51):

(49) Na mně se projevila určitá zdravotní indispozice. Ráno jsem vstával se zvýšenou teplotou, navícjsem měl nějaké střevní potíže.

(50) Obžalovaná nedokázala vysvětlit, proč si vzala nůž a proč bodla. „Já měla strach, že se bude dál hádat, a ráno jsem vstávala ve čtvrt na pèt do práce..." rekla.

(51) Pavel Horváth včera prožil náročný den. „V pět ráno jsem vstával a letěl do Lisabonu, “ rekl Blesku exkluzívně po večerním podpisu smlouvy.

Tento typ kontextu se velice podobá textovým souvislostem, na něž jsme upozornili v předchozí studii (Esvan, 2011) věnované užívání verb dicendi ř́kat - ř́ici, kdy se nedokonavé sloveso uplatňuje v rámci uvedení určité události, která byla předložena prostřednictvím př́mé řeči. Tuto situaci reprezentuje př. (52):

(52) [...] př́jemně ho překvapilo, že ministr mezi vojáky vůbec príšel. „Jsem tady rok, a to je poprvé, co tu vidím někoho $v$ takovém postaveni." Samotný ministr se při př́chodu mezi vojáky raději predstavoval. „Dobrý den, já jsem ministr obrany,“ "ríkal mezi dveřmi pokojů. SYN2Oogpub

\section{e) Vlastní činnost představuje důsledek}

Obdobně jako v př́́kladech uvedených výše, ve kterých věty obsahující sloveso vstával(a) jsem poskytují určité vysvětlení, je možné užití tohoto imperfektiva pozorovat ve větách, jež samy o sobě poskytují informaci o způsobu uskutečnění dané činnosti, přičemž př́slušná událost je prezentována jako následek již dříve uvedeného. Tento typ kontextu ilustrují př. (53) a (54):

(53) „Jsem rád, že máme volno a delší víkend,“ konstatoval jeden z nich, Róbert Domanický. „Ránojsem vstával jako do školy ani jsem si neprispal. Pak jsem hned šel ke kamarádovi na počítač," ríkal.

(54) Obvykle se po zápase prevaluju tak do tř́, než usnu, ale po Američanech to šlo kupodi- 
vu hladce. Navíc se mi zdálo o manželce, takže to bylo moc př́jemné. Ještě ráno jsem vstával s pocitem vítězství. Byla to paráda. Ale stálo mě to spoustu sil. Po zápase mi bylo celkem špatně, asi jsem z toho vedra dostal úpal.

\section{f) Řečnická otázka}

V neposlední řadě lze poukázat na užívání imperfektiva v situacích, v nichž sloveso vstával(a) jsem specifikuje způsob či průvodní události týkající se vykonané činnosti, a to skrze řečnickou otázku, jako je tomu v př. (55).

(55) Soňa jim to slíbila a zeptala se Ivanky, zda by s ní mohla chodit do večerní školy, Ivanka řekla, že jasně, a Soňa zajásala (takže já si tady dodělám i svou maturitu!), lehla na svou válendu, št'astně si vzdychla - (je to možný, že dnes ráno jsem vstávala ještě jako služka u Jágrů...) a okamžitě usnula.

\subsubsection{Sled událostí: $\mathbf{N}=7$}

Jak bylo naznačeno výše $\mathrm{v}$ souvislosti s užíváním perfektiva vstát $\mathrm{v}$ minulém čase (viz oddíl 2.1), také sloveso vstávat se může uplatňovat v případě, že je v textu předkládána sekvence událostí, ovšem užití imperfektiva je výrazně méně frekventované. Verbum vstávat $\mathrm{v}$ minulém čase může být následováno a) nedokonavými i b) dokonavými slovesy.

\section{a) Následují další imperfektiva}

Toto uspořádání, které je poměrně vzácné, je možné sledovat ve dvou typech kontextů, totiž pokud imperfektivum, jenž následuje, 1. označuje stav nebo činnost, 2. je součástí řetězce událostí vyjádřených nedokonavými slovesy.

1. Pokud následující imperfektivum znázorňuje určitou aktivitu nebo stav, časově odpovídá činnosti vyjádřené slovesem vstával(a) jsem. Jedná se o druh textových souvislostí, jež se velmi podobá kontextu, na který jsme upozornili výše za pomoci př. (25)-(29). V tomto případě je však stav či událost zprostředkovaná nedokonavým slovesem z časového hlediska v souladu s předchozí činností vyjádřenou slovesem vstával(a) jsem. Tuto situaci reprezentují př. (56) a (57):

(56) V̌̌era ráno jsem vstával a v hlavě mèl nával, ale myšlenkami porád s ní.

(57) Ráno v šest jsem vstávala a u nás $v$ Otvovicích zpívali ptáci. Já se hihňala jako jelimánek, protože jsem si uvědomila, že jsem št́astná.

2. Verbum vstával(a) jsem může být zasazeno do sledu po sobě jdoucích událostí, jež jsou formulovány nedokonavými slovesy. Tento styl narace je v minulém čase poměrně vzácný a představuje způsob vyprávění, v němž převažuje užívání sloves dokonavých. Jak jsme ukázali v předchozích studiích (Esvan; 2015, 2016), imperfektiva se při popisu sekvence událostí uplatňují naopak dosti často v čase př́tomném, 
přičemž podle našeho názoru tento způsob vyprávění koresponduje se stylisticky příznakovou formou narace, a to prézentem registrujícím. Není bez zajímavosti, že užívání nedokonavých sloves $\mathrm{v}$ minulém čase se $\mathrm{v}$ rámci popisu následujících si událostí vykazuje určitou podobností s užíváním těchto sloves v čase přítomném. Dané události jsou představovány spíše izolovaně, a pozornost je tak usměrňována k jednotlivým činnostem, jako by mezi nimi nebyla souvislost. Při vyprávění v minulém čase se tedy setkáváme s kontexty, jež jsou typické pro naraci v prézentu, kdy lze zároveň poukázat na to, že popisované události bývají předkládány v rámci situace, při níž lze hovořit o určitém rozrušení či znepokojení ze strany vypravěče. Tento faktor ilustrují př. (58) (málem zabil clověka, kolena se mi třásly) a př. (59) (si vůbec nepamatuju, záchytka):

(58) Slezl jsem zpátky dolů domů a kolena se mi trásly až do rána jak po maratónu. Kerej jsem nedoběhl. Vždyt'jsem už málem zabil člověka. Ránojsem vstával. Snídal mramorovou bábovku a kakao. Šel pěšky do školy.

(59) Já si ten den vůbec nepamatuju, bylo mi z toho zle. Ráno jsem vstával, pak jsme popíjeli. Večer mě vzbudila policie, odvezli mě na záchytku.

Analogické užívání imperfektiv v minulém a přítomném čase lze znázornit za pomoci př. (60) a (61), v nichž se nacházejí obdobné kontexty jako v př. (58) a (59) výše, jež reflektují vyprávění o postavě vylekané či nemocné.

(60) „Babičko, hoří, utíkejte!“ křičí z plných plic. Babička otvírá oči, leká se, ale vstává a utíká pryč.

(61) Někdo mne pokládá na lehátko uvnitř vozu, měří mi tlak, dostávám jakousi injekci. Sanitka vyjíždí a já ztrácím vědomí.

\section{b) Následují perfektiva}

V některých případech je imperfektivum součástí řetězce událostí, kdy je sloveso vstával(a) jsem následováno perfektivy. Užití nedokonavého slovesa v rámci tohoto schématu je $\mathrm{v}$ narativních textech poměrně běžné a bylo by možné jej nazvat „uvádějícím imperfektivem“. Nedokonavé sloveso otvírá prríslušné vyprávění, přičemž vyvolává určité očekávání, jehož naplnění je následně uskutečněno popisem událostí, jež obvykle zprostředkovávají slovesa dokonavá (vyjma př́padného užití závěrečného imperfektiva). Tento způsob narace reprezentují př. (62) a (63): ${ }^{6}$

(62) - Jakjste měl rozvržený den? - Ráno jsem vstával šestou, uvařil jsem si, sbalil věci, stan a nástrahy na medvědy. 
(63) Ráno jsem vstával $v$ pưl sedmé. Udělal jsem si snídani, pak následovala ranní hygiena. Vzal jsem si blok, tužku a šel jsem do školy.

\subsubsection{Shrnutí}

Přestože při popisu po sobě jdoucích událostí lze užívat dokonavá i nedokonavá slovesa, na základě analýzy kontextů, v nichž se uplatňuje verbum vstával(a) jsem, se ukazuje, že na rozdíl od perfektivní formy tohoto slovesa, se imperfektivum užívá spíše v textech argumentačního typu. Obecně lze říci, že průvodní jevy dané aktivity bývají upřesněny a sama činnost je uváděna v protikladu $k$ dalším okolnostem, a to s ohledem na následující druhy kontextů: a) kontrast, b) následné vysvětlení či motivace, c) následný důsledek, d) sama činnost představuje vysvětlení, e) sama činnost reprezentuje důsledek, f) řečnická otázka. Ve vzácných případech, v nichž je nedokonavé sloveso zasazeno do řetězce událostí v rámci určité narace, lze pro imperfektivum vymezit zvláštní funkce, kdy aktivita jím vyjádřená a) časově odpovídá jiné činnosti či stavu, b) je součástí stylisticky př́znakového způsobu narace, při němž je sekvence uváděných událostí reprezentována pouze nedokonavými slovesy, c) vyvolává určité napětí ve vyprávění, přičemž se uplatňuje uvádějící imperfektivum, jež následují dokonavá slovesa.

Statisticky lze uvedené druhy užívání slovesa vstávat v minulém čase znázornit následovně:

\begin{tabular}{|l|l|l|}
\hline & Počet výskytů & Užití v procentech \\
\hline Řetězec událostí & 7 & $19 \%$ \\
\hline Mimo řetězec událostí & 31 & $81 \%$ \\
\hline Celkem & 38 & $100 \%$ \\
\hline
\end{tabular}

\section{Závěr}

Rozbor kontextů, jež jsou sice určitým způsobem limitovány, ale zato se vyznačují poměrně vysokou frekvencí, poskytuje možnost poukázat na faktory, které mohou ovlivňovat výběr perfektiva nebo imperfektiva. Analýza dat excerpovaných z ČNK nám umožnila upozornit na některé významné aspekty, jež poukazují na nerovnocenné užívání sloves v rámci fenoménu konkurence vidů.

a) Lze vymezit dva typy kontextů, které zjevně ovlivňují výběr určitého aspektu. Je-li popisovaná událost předkládána $\mathrm{v}$ rámci sledu po sobě jdoucích událostí, ve vyprávění převažuje užití dokonavého slovesa, v př́padě diskurzu argumentačního typu je preferováno sloveso nedokonavé. Vliv těchto dvou faktorů se v obou př́padech potvrzuje ve výši $80 \%$.

b) Je možné poukázat na asymetrickou interpretaci výskytu perfektiv či imperfektiv, které nelze přímo podložit výše uvedenými aspekty. V textech argumentačního charakteru namísto očekavaných nedokonavých sloves nacházíme i slovesa 
dokonavá, která lze volně zaměnit za slovesa nedokonavá (viz př. (31)-(34)). Co se týče narativních textů, výběr příslušného vidu se naopak ukazuje jakožto významnější, jelikož vyjadřuje velmi jemné rozdíly v rámci obecných narativních modelů.

Lze říci, že rozbor dat ČNK umožňuje vyzdvihnout faktory usměrňující užití př́islušného vidu v minulém čase $v$ rámci specifického kontextu (zde konkrétně 1. osoby singuláru, přičemž dané textové souvislosti jsou upřesněny za pomoci adverbia ráno) a určité vidové dvojice (tedy sloves vstát - vstávat). Ačkoliv faktory ovlivňující volbu př́ślušného vidu, na něž jsme mohli v této studii poukázat, jsou obecného charakteru, nelze je při zkoumání imperfektiva ve faktuálním významu ukvapeně považovat za zcela spolehlivá pravidla. Zdá se, že užívání nedokonavého slovesa v kontextech faktuálního charakteru z velké části závisí také na sémantice daného verba, ${ }^{7}$ tedy faktoru, jenž byl při naší analýze poněkud upozaděn, jelikož jsme se zaměřili na rozbor kontextů obsahujících konkrétní vidovou dvojici.

\section{LITERATURA}

BERGER, Tilman. 2013. Ungewöhnliche Verwendungen des Aspekts im Tschechischen: der imperfektive Aspekt in Handlungssequenzen, Zeitschrift für Slawistik. 58(1), s. 31-42.

Dickey, Stephen M. 2000. Parameters of Slavic aspect. A cognitive approach, Stanford: CSLI Publ..

ECKERT, Eva. 1985. Aspect in repetitive contexts in Russian and Czech. In: FLIER, Michal S. TimberLAKe, Alan, eds. The scope of Slavic aspect. Columbus: Slavica, s. 169-180.

Esvan, François. 2000. Ke stř́dání vidu při vyprávění v češtině. In: Gramatika \& Korpus 2012, Hradec Králové: Gaudeamus, Univerzita Hradec Králové, s. 1-6.

EsvaN, François. 2006. Historický prézens v současné češtině: možnosti a meze jeho jazykových a komunikativních funkcí. In: ŠTícHA, František, ed. Možnosti a meze české gramatiky. Praha: Academia, s. 226-248.

Esvan, François. 2010. Notes sur l'usage de l'aspect verbal dans les subordonnées temporelles au passé en tchèque. In: Bertolissi, Sergio - SALVATORE, Roberta, eds. Forma formans. Studi in onore di B. A. Uspenskij. Napoli: D’Auria Editore, s. 179-191.

EsvaN, François. 2011. K vidové opozici u českých verb dicendi. Korpus-Gramatika-Axologie, 3, s. 45-56.

Esvan, François. 2015. Aspectual opposition in the different contexts of the historical present in Czech. In: BeNACCHIO, Rosanna, ed. Verbal Aspect: Grammatical Meaning and Context. München - Berlin - Washington/D.C: Verlag Otto Sagner, s. 211-216.

Esvan, François. 2017. Vid a čas v kontextu, In: KARLík, Petr - Nekula, Marek - PleskalovÁ, Jana, eds. Nový encyklopedický slovník češtiny N-Ž. Praha: Nakladatelství Lidové noviny, S. 1988-1991.

FORSYTH, James. 1970. A grammar of aspect. Usage and meaning in the Russian verb. Cambridge: Cambridge University press. 
GRøNN, Atle. 2003. The Semantics and Pragmatics of the Russian Factual Imperfective. Oslo, Ph.D. dissertation, University of Oslo.

GRøNN, Atle. 2008. Imperfectivity and complete events. In: JOSEPHSON, Folke - SöHRMAN, Ingmar, eds. Interdependence of Diachronic and Synchronic Analyses. Amsterdam: John Benjamins, s. 149-165.

Chlumská, Lucie. 2011. Kdo to přeložil, nebo Kdo to překládal? Několik poznámek ke konkurenci vidů v češtině a jejich anglickým ekvivalentům. In: Korpusová lingvistika Praha 2011, 1. sv. Praha: Nakladatelství Lidové noviny.

KopEČNÝ, František. 1962. Slovesný vid v češtině, Praha: Nakladatelství ČSAV.

Mathesius, Vilém. 1938. O konkurenci vidů v českém vyjadřování slovesném. Slovo a slovesnost. 4(1), s. 15-19.

RAssudova, Olga. 1984. Aspectual usage in modern Russian. Moskva: Ruský jazyk.

SÉMON, Jean-Pierre. 2008. Des imperfectifs prétérits étranges... In: GUIRAUD-WEBER, Marguerite - ROUDET, Robert - ZAREMBA, Charles, eds. Etudes offertes à Marguerite Guiraud-Weber. Aix-en-Provence: PUP, s. 305-315.

ŠTícHA, František. 2013. Akademická gramatika spisovné češtiny. Praha: Academia.

Stunová, Anna. 2004. A contrastive Analysis of Russian and Czech Aspect: Invariance vs. Discourse. Amsterdam, Ph.D. dissertation, University of Amsterdam.

\title{
Korpusy
}

SYNv3

Český národní korpus - SYNv3 [online]. Ústav Českého národního korpusu FF UK, Praha. [cit. 30.03.2018], dostupné z: http://www.korpus.cz

SYN2009PUB

Český národní korpus - SYN2009PUB [online]. Ústav Českého národního korpusu FF UK, Praha [cit. 30.03.2018], dostupné z: http://www.korpus.cz

SYN2015

Český národní korpus - SYN2015 [online]. Ústav Českého národního korpusu FF UK, Praha [cit. 30.03.2018], dostupné z: http://www.korpus.cz

\author{
François Esvan \\ Department of Literary, Linguistics and Comparative Studies \\ "L'Orientale" University of Naples \\ Palazzo Santa Maria Porta Coeli \\ Via Duomo 219, 80138 Napoli \\ Italy \\ esvanf@unior.it
}


